\title{
Occult HBV Infection in Pregnant Women in Northern Benin
}

\author{
Massimo De Paschale ${ }^{1^{*}}$, Cristina Ceriani ${ }^{1}$, Teresa Cerulli ${ }^{1}$, Debora Cagnin ${ }^{1}$, Serena Cavallari ${ }^{1}$, Joseph \\ Ndayake $^{2}$, Dieudonné Zaongo ${ }^{2}$, Kouma Diombo ${ }^{2}$, Gianbattista Priuli ${ }^{2}$, Paolo Viganò ${ }^{3}$ and Pierangelo \\ Clerici $^{1}$
}

${ }^{1}$ Microbiology Unit, ASST Ovest Milanese, Hospital of Legnano, Italy

${ }^{2}$ Hôpital Saint Jean de Dieu, Tanguiéta, Benin

${ }^{3}$ Department Infectious Diseases, ASST Ovest Milanese, Hospital of Legnano, Italy

*Corresponding author: Massimo De Paschale, Microbiology Unit, ASST Ovest Milanese, Hospital of Legnano, Via Papa Giovanni Paolo II, 20025 Legnano, Milan, Italy, Tel: +39-0331-449-319, Fax +39-0331-449578

\begin{abstract}
Background and methods: Occult infections (OBIs) due to hepatitis $B$ virus (HBV) are identified by the presence of HBV DNA without surface antigen ( $\mathrm{HBsAg})$. The population prevalence of $\mathrm{HBsAg}$ is high in Benin, but there are no data concerning the presence of OBls.

The aim of this study was to evaluate the presence of OBIs using samples taken from 220 pregnant Beninese women for the purposes of a previous study of the prevalence of HBV markers. Twenty-four women were HBsAg positive (group I); of the $196 \mathrm{HBsAg}$ negative women, 164 had other HBV markers (group II) and 32 had no HBV marker at all (group III).

Results: Forty-seven (24.0\%) of the HBsAg-negative samples were positive for HBV DNA of which 46 (97.9\%) in group II (seropositive OBIs) and $1(2.1 \%)$ in group III (seronegative OBIs). About half of the women in groups II had viremia levels of $<20 \mathrm{IU} / \mathrm{mL}$; the mean viremia levels in the remaining samples were $188.7 \mathrm{IU} / \mathrm{mL}$ in group II, although some of the women with OBls had levels of as high as $1187 \mathrm{IU} / \mathrm{mL}$.

Conclusion: The high prevalence of OBls increases the number of potentially infected subjects in this area in comparison with the findings of tests based on the determination of $\mathrm{HBsAg}$ alone, which significant clinical and management implications for both vertical and horizontal transmission.
\end{abstract}

\section{Keywords}

HBV DNA, Occult hepatitis, Pregnant women, Anti-HBc alone, Occult infections

\section{Introduction}

Occult infection (OBI) due to hepatitis B virus (HBV) is best defined as the presence of HBV DNA in the liver (with or without serum HBV DNA) in the absence of detectable serum HBV surface antigen (HBsAg) [1] because viral DNA can be detected in the liver even when it is not found in blood [2] However, as obtaining liver HBV DNA is difficult in clinical practice and there are still no appropriately standardised tests for detecting it in liver tissue [3], it is more usually defined as the presence of normally low levels $(<200 \mathrm{IU} / \mathrm{mL}$ ) of serum HBV DNA without any determinable $\mathrm{HBsAg}[1,3,4]$.

This situation can be found in the case of: 1) Patients recovering from $\mathrm{HBV}$ infection with anti-HBsAg antibodies (anti-HBs) and viral persistence after $\mathrm{HBsAg}$ has disappeared $[5,6]$; 2) Patients with chronic hepatitis with a mutant $\mathrm{HBV}$ gene $\mathrm{S}$ (encoding for $\mathrm{HBsAg}$ ) and the production of modified HBsAg that cannot be detected by widely used commercial tests ("false OBI") whose viremic levels are comparable with those observed in patients with normal HBV infection [1,4,7]; 3) Chronic carriers without any marker of HBV infection because of the progressive loss of all anti-HBV antibodies or the absence of antibodies from the beginning [8]; 4) Patients co-infected with hepatitis $\mathrm{C}$ virus (HCV) in whom the $\mathrm{HCV}$ core protein interferes with the replication of HBV and the synthesis of its proteins [9], or co-infected with human immunodeficiency virus (HIV) due to cell 
immunodeficiency (decreased CD4+ cell numbers) [10]; 5) Chronic carriers with undetectable unmutated HBsAg in whom the only serological marker is the presence of antibodies to the antigen of the HBV core (anti-HBc), a situation that is often found in areas where HBV is endemic [11].

Occult infections have been divided into seropositive OBIs (the presence of anti-HBc and/or anti-HBs) and seronegative OBIs (the absence of anti-HBc and antiHBs) on the basis of serum HBV antibody profiles [12]. About $20 \%$ of all OBIs are seronegative, $50 \%$ are anti$\mathrm{HBc}$ seropositive (with or without anti-HBs), and $35 \%$ are anti-HBs seropositive [13].

The prevalence of OBIs varies widely [12] as it depends on factors such as geographical area (endemicity), the characteristics of the patients, including co-morbidities such as HCV and/or HIV, and the sensitivity of the diagnostic technique $[1,14]$ It may also depend on the nature of the tested biological material as the liver is more likely to be positive than serum [15]. In geographical terms, it has been reported that the population prevalence of $\mathrm{OBI}$ is as high as up to $25 \%$ [16-21] in highly endemic areas such as Africa and Asia, where 41$95 \%$ of the inhabitants have been exposed to HBV, and lower in areas such as North America or Europe, where only $5-20 \%$ of the inhabitants have been exposed [22].

In Africa, the prevalence of $\mathrm{HBsAg}$ is $8-20 \%$ and that of the markers of exposure to HBV (anti-HBc with or without anti-HBs) is 70-95\% [23]. Studies of OBIs in subSaharan countries have mainly focused on particular groups of subjects such as HIV-positive patients, among whom their prevalence is $10-23 \%$ [24-29] or blood donors, who are characterised by a prevalence of 0.5 $17 \%$ [30-33] but there are very few studies of pregnant women [31,34].

There are no data concerning OBIs in Benin, although an article concerning asymptomatic pregnant women in a rural area in northern Benin published in 2014 stated that the prevalence of $\mathrm{HBsAg}$ was $15.5 \%$, and that of anti-HBc alone was $41.3 \%$ [35]. As many of the samples used for that study were still available for HBV DNA research, the aim of this study was to determine the prevalence of occult HBV infection in this group of women.

\section{Methods}

In 2011, 283 asymptomatic pregnant women who sequentially attended the Saint Jean de Dieu de Tanguiéta Hospital (located in the rural district of Atacora in the north of Benin) for HIV screening were also examined for markers of $\mathrm{HBV}$ and $\mathrm{HCV}: 15.5 \%$ were $\mathrm{HBsAg}$ positive, $41.3 \%$ anti-HBc positive alone, $7.4 \%$ anti-HCV positive, and $3.2 \%$ anti-HIV positive [35].

Plasma samples from 220 of these women (mean age 26.2 years, range $15-40$ ) were sterilely separated and frozen, and became subsequently available for
HBV DNA research. On the basis of the results obtained in 2011, the samples were divided into three groups: group I) $24 \mathrm{HBsAg-positive} \mathrm{samples} \mathrm{(10.9 \% );} \mathrm{group} \mathrm{II)}$ 164 HBsAg-negative samples positive for anti-HBc and/ or anti-HBs markers of HBV (74.5\%); and group III) 32 samples that were negative for $\mathrm{HBsAg}$, anti-HBs and anti-HBc (14.5\%). Five of the women (2.3\%) were antiHIV positive (all in group II) and 11 (5.0\%) anti-HCV positive (one in group I and ten in group II). There were no statistically significant differences between these 220 women and the initial group of 283 women in terms of age, or HBV, HCV and HIV markers.

The search for HBV DNA was made using a realtime method (AmpliPrep/COBAS TaqMan HBV Test, version 2.0, Roche Diagnostics, Mannheim, Germany), the results of which are linear from $20 \mathrm{IU} / \mathrm{mL}$ to 1.7 $\times 10^{8} \mathrm{IU} / \mathrm{mL}$. The amount of DNA was recorded in IU/ $\mathrm{mL}$ if it was $>20 \mathrm{IU} / \mathrm{mL}$, "not detectable" if none was detected, or " $<20 \mathrm{IU} / \mathrm{mL}^{\prime}$ " if the amount was below the linearity of the test but above the sensitivity stated by the manufacturer ( $95 \%$ for plasma levels of $9 \mathrm{lU} / \mathrm{mL}$ ). The samples with $<20 \mathrm{IU} / \mathrm{mL}$ result were retested.

The HBV DNA-positive samples also underwent a chemiluminescent immunoassay (CLIA) for HBsAg (LIAISON XL MUREX HBsAg Quant, DiaSorin, Saluggia, Italy) that was different from that used in the previous study.

The data were statistically analysed using SPSS software, version 16.0 (SPSS Inc., Chicago, IL), and the chi-squared and Fisher's exact test to evaluate the differences between percentages, and analysis of variance (ANOVA) to evaluate the differences between the quantitative values.

\section{Results}

HBV DNA was detected in 68 of the 220 samples (30.9\%): 43 with levels of $>20 \mathrm{IU} / \mathrm{mL}(19.5 \%)$ and 25 with repeatedly levels of $<20 \mathrm{IU} / \mathrm{mL}$ (11.4\%). Among the $196 \mathrm{HBsAg-negative} \mathrm{samples} \mathrm{(groups} \mathrm{II} \mathrm{+} \mathrm{III),} 47$ (24.0\%; 95\% Cl: 18.02-29.98) were HBV DNA positive: 26 (13.3\% 95\% Cl: 8.55-18.05) with levels of > $20 \mathrm{IU} /$ $\mathrm{mL}$, and 21 (10.7\%; 95\% Cl: 6.37-15.03) with levels of $<20 \mathrm{IU} / \mathrm{mL}$. Table 1 shows the results by group. The differences in the total percentage of samples with HBV DNA among the tree groups were statistically significant $(p<0.01)$. Of the 47 HBV DNA-positive and HBsAg-negative subjects (groups II and III), 1 (2.1\%) were in group III (HBsAg/anti-HBs/anti-HBc negative) and 46 (97.9\%) in group II (HBsAg negative and anti$\mathrm{HBC}$ and/or anti-HBs positive), including two (4.2\%) in subgroup Ila (HBsAg-/anti-HBs+/anti-HBc-), 26 (55.3\%) in subgroup IIb (HBsAg-/anti-HBs-/anti-HBc+) and 18 (38.3\%) in subgroup Ilc (HBsAg-/anti-HBst/anti-HBc+). Table 2 shows the results by subgroup There were no statistically significant differences between the three subgroups. 
Table 1: HBV DNA in pregnant Beninese women divided on the basis of the presence/absence of HBV markers and DNA levels.

\begin{tabular}{|c|c|c|c|c|c|}
\hline \multirow[t]{2}{*}{ Group } & \multirow[t]{2}{*}{ No. } & \multirow[t]{2}{*}{ HBV Markers } & \multicolumn{3}{|c|}{ HBV DNA Positivity } \\
\hline & & & $\begin{array}{l}>20 \mathrm{IU} / \mathrm{mL} \\
(95 \% \mathrm{Cl})\end{array}$ & $\begin{array}{l}<20 \mathrm{IU} / \mathrm{mL} \\
(95 \% \mathrm{Cl})\end{array}$ & $\begin{array}{l}\text { Total } \\
(95 \% \mathrm{Cl})\end{array}$ \\
\hline 1 & 24 & HBsAg positive & $\begin{array}{l}17(70.8 \%) \\
(52.60-88.99)\end{array}$ & $\begin{array}{l}4(16.7 \%) \\
(1.78-31.62)\end{array}$ & $\begin{array}{l}21(87.5 \%) \\
(74.27-100)\end{array}$ \\
\hline II & 164 & HBsAg negative (anti-HBc and/or anti-HBs positive) & $\begin{array}{l}25(15.2 \%) \\
(9.71-20.69)\end{array}$ & $\begin{array}{l}21(12.8 \%) \\
(7.69-17.91)\end{array}$ & $\begin{array}{l}46(28.0 \%) \\
(21.13-34.87)\end{array}$ \\
\hline III & 32 & HBsAg/anti-HBs/anti-HBc negative & $\begin{array}{l}1(3.1 \%) \\
(0.00-9.11)\end{array}$ & $\begin{array}{l}0(0 \%) \\
(0.00-0.00)\end{array}$ & $\begin{array}{l}1(3.1 \%) \\
(0.00-9.11)\end{array}$ \\
\hline Total & 220 & & $\begin{array}{l}43(19.5 \%) \\
(14.26-24.74)\end{array}$ & $\begin{array}{l}25(11.4 \%) \\
(7.20-15.60)\end{array}$ & $\begin{array}{l}68(30.9 \%) \\
(24.79-37.01)\end{array}$ \\
\hline
\end{tabular}

Table 2: HBV DNA levels in HBsAg-negative pregnant Beninese women divided on the basis of the presence of specific HBV antibodies.

\begin{tabular}{|c|c|c|c|c|c|}
\hline \multirow{2}{*}{$\begin{array}{l}\text { Sub } \\
\text { group }\end{array}$} & \multirow[t]{2}{*}{ No. } & \multirow[t]{2}{*}{ HBV Markers } & \multicolumn{3}{|c|}{ HBV DNA Positivity } \\
\hline & & & $\begin{array}{l}>20 \mathrm{IU} / \mathrm{mL} \\
(95 \% \mathrm{Cl})\end{array}$ & $\begin{array}{l}<20 \mathrm{IU} / \mathrm{mL} \\
(95 \% \mathrm{Cl})\end{array}$ & $\begin{array}{l}\text { Total } \\
(95 \% \mathrm{Cl})\end{array}$ \\
\hline Ila & 9 & HBsAg-/anti-HBs+/anti-HBc- & $\begin{array}{l}1(11.1 \%) \\
(0.00-31.62)\end{array}$ & $\begin{array}{l}1(11.1 \%) \\
(0.00-31.62)\end{array}$ & $\begin{array}{l}2(22.2 \%) \\
(0.00-49.35)\end{array}$ \\
\hline IIb & 94 & HBsAg-/anti-HBs-/anti-HBc+ & $\begin{array}{l}16(17.0 \%) \\
(9.41-24.59)\end{array}$ & $\begin{array}{l}10(10.6 \%) \\
(4.38-16.82)\end{array}$ & $\begin{array}{l}26(27.6 \%) \\
(18.56-36.64)\end{array}$ \\
\hline IIc & 61 & HBsAg-/anti-HBs+/anti-HBc+ & $\begin{array}{l}8(13.1 \%) \\
(4.63-21.57)\end{array}$ & $\begin{array}{l}10(16.4 \%) \\
(7.11-25.69)\end{array}$ & $\begin{array}{l}18(29.5 \%) \\
(18.06-40.94)\end{array}$ \\
\hline Total & 164 & & $\begin{array}{l}25(15.2 \%) \\
(9.71-20.69)\end{array}$ & $\begin{array}{l}21(12.8 \%) \\
(7.69-17.91)\end{array}$ & $\begin{array}{l}46(28.0 \%) \\
(21.13-34.87)\end{array}$ \\
\hline
\end{tabular}

Table 3: Relationships between the samples with HBV DNA levels of $>20$ and $<20 \mathrm{IU} / \mathrm{mL}$ in pregnant Beninese women divided on the basis of the presence/absence of HBV markers.

\begin{tabular}{|c|c|c|c|c|}
\hline \multirow[t]{2}{*}{ Group } & \multirow[t]{2}{*}{ HBV Markers } & \multicolumn{3}{|c|}{ HBV DNA Positivity } \\
\hline & & Total & $\begin{array}{l}>20 \mathrm{IU} / \mathrm{mL} \\
(95 \% \mathrm{Cl})\end{array}$ & $\begin{array}{l}<20 \mathrm{IU} / \mathrm{mL} \\
(95 \% \mathrm{Cl})\end{array}$ \\
\hline I & HBsAg positive & 21 & $\begin{array}{l}17(81.0 \%) \\
(64.22-97.78)\end{array}$ & $\begin{array}{l}4(19.0 \%) \\
(2.22-35.78)\end{array}$ \\
\hline II & HBsAg negative (anti-HBc and/or anti-HBs positive) & 46 & $\begin{array}{l}25(54.3 \%) \\
(39.90-68.69)\end{array}$ & $\begin{array}{l}21(45.7 \%) \\
(31.30-60.10)\end{array}$ \\
\hline III & HBsAg/anti-HBs/anti-HBc negative & 1 & $1(100 \%)$ & $0(0 \%)$ \\
\hline Total & & 68 & $\begin{array}{l}43(63.2 \%) \\
(51.74-74.66)\end{array}$ & $\begin{array}{l}25(36.8 \%) \\
(25.34-48.26)\end{array}$ \\
\hline
\end{tabular}

About the viral load, the differences in the percentage of samples with HBV DNA levels of $>20 \mathrm{IU} / \mathrm{mL}$ between group I (HBsAg positive) and groups II or III (HBsAg negative) were statistically significant $(p<0.01)$, but not those between groups II and III. Furthermore, there was difference in the percentage of samples with levels of < $20 \mathrm{IU} /$ $\mathrm{mL}$ between group I and group III or between group II and group III (<0.05), but not between groups I and II (Table 1).

The ratios between the samples with HBV DNA levels of $>20$ and $<20 \mathrm{IU} / \mathrm{mL}$ is also shown in Table 3 and the difference between group I and group II was statistically significant $(p<0.05)$.

Table 4 shows the mean, median and range of HBV DNA levels in the samples with levels of $>20 \mathrm{IU} / \mathrm{mL}$. The difference between group I and II ( $p<0.05)$ was statistically significant.

In terms of co-infections, none of the HIV-positive women and only one of the HCV-positive women was 
Table 4: Mean, median and range of HBV DNA levels in the samples with levels of $>20 \mathrm{IU} / \mathrm{mL}$ divided on the basis of the presence/absence of HBV markers.

\begin{tabular}{|l|l|l|l|l|l|}
\hline Group & HBV Markers & \multicolumn{4}{l|}{ HBV DNA Positivity } \\
\hline & & No. & Mean (IU/mL) & Median (IU/mL) & Range (IU/mL) \\
\hline I & HBsAg positive & 17 & $122,086.30$ & 405.5 & $31-881,539$ \\
\hline II & HBsAg negative (anti-HBc and/or anti-HBs positive) & 25 & 188.7 & 91 & $24-1187$ \\
\hline III & HBsAg/anti-HBs/anti-HBc negative & 1 & 47 & 47 & \\
\hline Total & & 43 & 46,622 & 116.5 & $24-881,539$ \\
\hline
\end{tabular}

Table 5: HBV DNA results by HBV markers and age.

\begin{tabular}{|c|c|c|c|c|c|c|}
\hline \multirow[t]{2}{*}{ Group } & \multirow[t]{2}{*}{ No. } & \multirow[t]{2}{*}{ HBV Markers } & \multicolumn{2}{|c|}{ Positive for HBV DNA } & \multicolumn{2}{|c|}{ Negative for HBV DNA } \\
\hline & & & No. & $\begin{array}{l}\text { Mean age in } \\
\text { years (range) }\end{array}$ & No. & $\begin{array}{l}\text { Mean age in } \\
\text { years (range) }\end{array}$ \\
\hline 1 & 24 & HBsAg positive & 21 & $\begin{array}{l}27.5 \\
(18-38)\end{array}$ & 3 & $\begin{array}{l}27.7 \\
(25-32)\end{array}$ \\
\hline II & 164 & HBsAg negative (anti-HBc and/or anti-HBs positive) & 46 & $\begin{array}{l}26.9 \\
(15-40)\end{array}$ & 118 & $\begin{array}{l}26.2 \\
(17-40)\end{array}$ \\
\hline III & 32 & HBsAg/anti-HBs/anti-HBc negative & 1 & 31.0 & 31 & $\begin{array}{l}25.1 \\
(18-37)\end{array}$ \\
\hline Total & 220 & & 68 & $\begin{array}{l}27.1 \\
(15-40)\end{array}$ & 152 & $\begin{array}{l}26.0 \\
(17-40)\end{array}$ \\
\hline
\end{tabular}

positive for HBV DNA (and HBsAg negative) in group II.

With the aim of confirming the HBsAg results of the previous study, all samples, which were negative for HBsAg and positive for HBV-DNA, were retested with the CLIA test (that was different from that used in the previous study). All these samples were HBsAg negative with the CLIA test.

Table 5 shows the HBV results by age and the presence/absence of HBV markers. The between-group differences in age and the differences in age between the women with and without HBV DNA were not statistically significant. There was also no significant difference in age between the women with $>20 \mathrm{IU} / \mathrm{mL}$ and those with $<20 \mathrm{IU} / \mathrm{mL}$ in any of the groups.

\section{Discussion}

HBV infection is highly endemic in Benin: a study of pregnant women carried out in 2011 found that $15.5 \%$ were $\mathrm{HBsAg}$ positive but $41.3 \%$ were positive for anti-HBc [35]. As the presence of anti-HBc alone can identify chronic HBV carriers in highly endemic areas even if they are HBsAg negative [11], the suspicion that $\mathrm{OBI}$ may also be highly prevalent in Benin led us to look for HBV DNA in the blood samples still available from the 2011 study. Our findings suggest that $24 \%$ of the samples indicated $\mathrm{OBI}$ as they showed the presence of HBV DNA in the absence of $\mathrm{HBsAg}$. This figure is similar or slightly higher than that found in other studies carried out in Africa, which have reported OBI prevalence rates of $10-23 \%$ among HIV-positive subjects [24,26-29], 17\% among blood donors [32], but much higher than that found in pregnant women with prevalence of about
$2 \%[31,34]$. On the other hand, one study carried out in Nigeria (which borders on Benin) found a prevalence of $36 \%$ among patients attending a hospital Emergency Department [36]. However, the Nigerian study found that about $60 \%$ of the patients were co-infected with HIV, whereas the prevalence of co-infection in the Benin study was only $2.3 \%$, which reflects the low prevalence of HIV infection in the general population of Benin at the time the blood samples were taken [35].

The high prevalence of $\mathrm{OBI}$ in countries such as Benin where HBV is endemic may be related to the fact that most of these infections are contracted perinatally or during early childhood and, as such infections are often chronic, there is a correspondingly proportion of adults with chronic infection, including some without determinable HBsAg levels [37]. In countries where the disease is less endemic, transmission is mainly horizontal [38].

Almost all the OBIs identified in this study (97.9\%) were seropositive OBIs associated with markers of HBV, especially isolated anti-HBc (55.3\%) and there was no age-related difference in the presence or absence of viremia.

The viral load in the women with seropositive OBIs was very low ( $<20 \mathrm{IU} / \mathrm{mL}$ in almost half of the cases), and significantly different from that observed in the HBsAgpositive women in line with published data $[1,3,4]$. The method used by our centre has a declared sensitivity of $9 \mathrm{lU} / \mathrm{mL}$ for plasma (although the linearity of the test starts from $20 \mathrm{IU} / \mathrm{mL}$ ), and thus approaches the HBV DNA detection limit of $5 \mathrm{IU} / \mathrm{mL}$ suggested as indicating $\mathrm{OBI}[3]$. It can therefore be assumed that about half of 
the OBIs identified in this study were characterised by HBV DNA levels of between 9 and $19 \mathrm{lU} / \mathrm{mL}$, and this sensitivity may explain the high prevalence of $\mathrm{OBI}$ in comparison with other studies. On the other hand, it is necessary to bear in mind that HBV DNA levels may fluctuate over time $[39,40]$, and so patients should really be evaluated serially in order to determine whether they have a chronic infection with a progressive loss of all anti-HBV antibodies, or whether they were devoid of antibodies from the beginning [8]. Unfortunately, we do not have any subsequent data: The women who had been screened for HIV were no longer traceable and, as the women were asymptomatic for liver disease at the time of HIV screening and the HBV marker prevalence study was performed retrospectively, there are no biochemical liver data that can be associated with OBI.

In an attempt to explain the presence of chronic HBV carriers without $\mathrm{HBsAg}$, we investigated the possibilities that HCV may have interfered with HBV replication [9] or that HIV may have caused cellular immunodeficiency [10]. However, none of the woman with OBI had HIV infection and only one had HCV infection, so the presence of $\mathrm{OBI}$ therefore did not seem to have been due to viral interference.

It has been suggested that viremia may be partially kept under control as a result of a cytotoxic response by $T$ lymphocytes after the resolution of an acute infection [41]. It is not known why the eradication is not complete, but it has been hypothesised that the occurrence of mutants in the $S$ region may explain the persistence of viremia, although it has also been reported that more than half of the subjects without apparent mutations in the $S$ gene have OBIs [36]. We re-tested our HBV DNA-positive and HBsAg- negative samples using a different test from that used in the previous study that is capable of detecting the most frequent mutants of HBV [42] because it has been suggested that HBsAg should be tested in this way [2]. With this test all samples were negative according to OBIs are characterised by undetectable HBV DNA and non-mutated HBsAg levels [11]. The presence of other possible mutations that may generate escape-mutants was not investigated because it was impossible to sequence the samples. Other immunological factors that may be involved include a non-cytolytic T lymphocyte response to specific HBsAg [43].

It has been suggested that different HBV genotypes may at least partially explain the existence of patients with or without HBsAg [44], but only a few studies $[45,46]$ have provided a complete genomic sequence, not least because of the difficulty of amplifying a complete genome in samples with low levels of HBV DNA [4]. It has been possible to detect sufficient levels of viremia to determine the genotypes of Beninese women with positive $\mathrm{HBsAg}$ [35] but this was not possible in the case of our women with OBIs because the remaining samples were too small.
Another limitation of this study is that we have no information concerning the children of these women that would make it possible to estimate the rate of vertical/perinatal transmission. Animal-based studies have shown maternal-fetal transmission in marmots with maternal occult infection [47], leading to the production of persistent, seronegative and asymptomatic infection in their offspring. Vertical transmission has also been postulated in humans [3], and it has been reported that a baby of a mother with OBI was positive for HBV DNA at birth [34]. Some authors believe that neonatal transmission through cord blood from mothers with OBI is not a clinical problem because of the low levels of HBV DNA [48], but some of our women with OBI had HBV DNA levels that were as high as $1187 \mathrm{IU} / \mathrm{mL}$, which could be sufficient for HBV transmission.

In conclusion, this study found a high prevalence of both seropositive and seronegative OBIs in Benin that has various clinical, organisational and epidemiological implications. The significant proportion of OBIs increases the number of HBV carriers who may transmit the virus vertically/perinatally (screening for maternal $\mathrm{HBsAg}$ may be insufficient and should perhaps be supported by neonatal immunoprophylaxis), but also horizontally (for example, a negative HBsAg test does not guarantee a sufficient level of safety for transfusion services) [43]. A vaccination campaign was started in Benin in 1999 [49], but the administration of immunoglobulins to newborns in order to prevent perinatal infection may also be required $[49,50]$.

\section{Conflict of interest}

The Authors declare NO financial or other relationships that may involve conflicts of interests.

\section{Experimental Ethics}

The study was approved by the Hôpital Saint Jean de Dieu medical direction and informed consent was obtained for patients.

\section{Acknowledgements}

We are grateful to the 'Gruppo Solidarieta'Africa' (GSA), whose active collaboration made it possible to carry out the study.

\section{References}

1. Raimondo G, Allain JP, Brunetto MR, Buendia MA, Chen DS, et al. (2008) Statements from the Taormina expert meeting on occult hepatitis B virus infection. J Hepatol 49: 652-657.

2. Ocana S, Casas ML, Buhigas I, Lledo JL (2011) Diagnostic strategy for occult hepatitis B virus infection. World $\mathrm{J}$ Gastroenterol 17: 1553-1557.

3. Hollinger FB, Sood G (2010) Occult hepatitis B virus infection: A covert operation. J Viral Hepat 17: 1-15.

4. Bréchot $C$, Thiers $V$, Kremsdorf D, Nalpas B, Pol S, et al. (2001) Persistent hepatitis B virus infection in subjects without hepatitis B surface antigen: Clinically significant or purely "occult"? Hepatology 34: 194-203. 
5. Hollinger FB (2008) Hepatitis B virus infection and transfusion medicine: science and the occult. Transfusion 48: 1001-1026.

6. Allain JP, Candotti D (2009) Diagnostic algorithm for HBV safe transfusion. Blood Transfus 7: 174-182.

7. Weber B (2006) Diagnostic impact of the genetic variability of the hepatitis $B$ virus surface antigen gene. J Med Virol 78: S59-S65.

8. Pollicino T, Raimondo G (2014) Occult hepatitis B infection. J Hepatol 61: 688-689.

9. Lee WM (1997) Hepatitis B virus infection. N Engl J Med 337: 1733-1745.

10. Cohen Stuart JW, Velema M, Schuurman R, Boucher CA, Hoepelman Al (2009) Occult hepatitis B in persons infected with HIV is associated with low CD4 counts and resolves during antiretroviral therapy. J Med Virol 81: 441-445.

11. Allain JP (2004) Occult hepatitis B virus infection. Transfus Clin Biol 11: 18-25.

12. Kwak MS, Kim YJ (2014) Occult hepatitis B virus infection. World J Hepatol 6: 860-869.

13. Torbenson M, Thomas DL (2002) Occult hepatitis B. Lancet Infect Dis 2: 479-486.

14. Samal J, Kandpal M, Vivekanandan P (2012) Molecular mechanisms underlying occult hepatitis $B$ virus infection. Clin Microbiol Rev 25: 142-163.

15. Chemin I, Trépo C (2005) Clinical impact of occult HBV infections. J Clin Virol 34: S15-S21.

16. Shih LN, Sheu JC, Wang JT, Huang GT, Yang PM, et al (1990) Serum hepatitis B virus DNA in healthy HBsAgnegative Chinese adults evaluated by polymerase chain reaction. J Med Virol 32: 257-260.

17. Kao JH, Chen PJ, Lai MY, Chen DS (2002) Occult hepatitis $B$ virus infection and clinical outcomes of patients with chronic hepatitis C. J Clin Microbiol 40: 4068-4071.

18. Minuk GY, Sun DF, Uhanova J, Zhang M, Caouette S, et al. (2005) Occult hepatitis B virus infection in a North American community-based population. J Hepatol 42: 480-485.

19. Liu CJ, Chen DS, Chen PJ (2006) Epidemiology of HBV infection in Asian blood donors: emphasis on occult HBV infection and the role of NAT. J Clin Virol 36: S33-S44.

20. Kim SM, Lee KS, Park CJ, Lee JY, Kim KH, et al. (2007) Prevalence of occult HBV infection among subjects with normal serum ALT levels in Korea. J Infect 54: 185-191.

21. Fang Y, Shang QL, Liu JY, Li D, Xu WZ, et al. (2009) Prevalence of occult hepatitis $B$ virus infection among hepatopathy patients and healthy people in China. J Infect 58: 383-388

22. Conjeevaram HS, Lok AS (2001) Occult hepatitis B virus infection: A hidden menace? Hepatology 34: 204-206.

23. Modi AA, Feld JJ (2007) Viral hepatitis and HIV in Africa. AIDS Rev 9: 25-39.

24. Mphahlele MJ, Lukhwareni A, Burnett RJ, Moropeng LM, Ngobeni JM (2006) High risk of occult hepatitis B virus infection in HIV-positive patients from South Africa. J Clin Virol 35: 14-20.

25. Firnhaber C, Viana R, Reyneke A, Schultze D, Malope B, et al. (2009) Occult hepatitis B virus infection in patients with isolated core antibody and HIV co-infection in an urban clinic in Johannesburg, South Africa. Int $\mathrm{J}$ Infect Dis 13:
488-492.

26. Lukhwareni A, Burnett RJ, Selabe SG, Mzileni MO, Mphahlele MJ (2009) Increased detection of HBV DNA in HBsAg-positive and HBsAg-negative South African HIVIAIDS patients enrolling for highly active antiretroviral therapy at a Tertiary Hospital. J Med Virol 81: 406-412.

27. N'Dri-Yoman T, Anglaret X, Messou E, Attia A, Polneau S, et al. (2010) Occult HBV infection in untreated HIV-infected adults in Côte d'Ivoire. Antivir Ther 15: 1029-1034.

28. Attia KA, Eholié S, Messou E, Christine Danel, Sandrine Polneau, et al. (2012) Prevalence and virological profiles of hepatitis $B$ infection in human immunodeficiency virus patients. World J Hepatol 4: 218-223.

29. Mudawi $H$, Hussein $W$, Mukhtar M, Yousif M, Nemeri $O$, et al. (2014) Overt and occult hepatitis B virus infection in adult Sudanese HIV patients. Int J Infect Dis 29: 65-70.

30. Allain JP, Candotti D, Soldan K, Sarkodie F, Phelps B, et al. (2003) The risk of hepatitis B virus infection by transfusion in Kumasi, Ghana. Blood 101: 2419-2425.

31. Zahn A, Li C, Danso K, Candotti D, Owusu-Ofori S, et al. (2008) Molecular characterization of occult hepatitis B virus in genotype E-infected subjects. J Gen Virol 89: 409-418.

32. Oluyinka OO, Van Tong $H$, Bui Tien S, Fagbami $A H$, Adekanle O, et al. (2015) Occult Hepatitis B Virus Infection in Nigerian Blood Donors and Hepatitis B Virus Transmission Risks. PLoS One 10: e0131912.

33. Nna E, Mbamalu C, Ekejindu I (2014) Occult hepatitis $B$ viral infection among blood donors in South-Eastern Nigeria. Pathog Glob Health 108: 223-228.

34. Hoffmann CJ, Mashabela F, Cohn S, Hoffmann JD, Lala S, et al. (2014) Maternal hepatitis B and infant infection among pregnant women living with HIV in South Africa. J Int AIDS Soc 17: 18871.

35. De Paschale M, Ceriani C, Cerulli T, Cagnin D, Cavallari S, et al. (2014) Prevalence of HBV, HDV, HCV, and HIV Infection During Pregnancy in Northern Benin. J Med Virol 86: 1281-1287.

36. Apica BS, Seremba E, Rule J, Yuan HJ, Lee WM (2016) High prevalence of occult hepatitis B infection in an African urban population. J Med Virol 88: 674-680.

37. Said ZN (2011) An overview of occult hepatitis B virus infection. World J Gastroenterol 17: 1927-1938.

38. Liu CJ, Lo SC, Kao JH, Tseng PT, Lai MY, et al. (2006) Transmission of occult hepatitis $B$ virus by transfusion to adult and pediatric recipients in Taiwan. J Hepatol 44: 39-46.

39. Gross A, Joller-Jemelka HI, Wicki AN, Grob PJ (1993) Hepatitis serological finding "anti-HBc alone", circulating viral DNA and interpretation of findings. Schweiz Med Wochenschr 123: 1193-1202.

40. Hofer M, Joller-Jemelka HI, Grob PJ, Lüthy R, Opravil M (1998) Frequent chronic hepatitis B virus infection in HIVinfected patients positive for antibody to hepatitis B core antigen only. Swiss HIV Cohort Study. Eur J Clin Microbiol Infect Dis 17: 6-13.

41. Rehermann B, Ferrari C, Pasquinelli C, Chisari FV (1996) The hepatitis B virus persists for decades after patients' recovery from acute viral hepatitis despite active maintenance of a cytotoxic T-lymphocyte response. Nat Med 2: 1104-1108.

42. De Paschale M, Manco MT, Belvisi L, Cagnin D, Cerulli T, et al. (2017) Evaluation of LIAISON ${ }^{\circledR}$ XL system for HBsAg, 
and anti-HCV and anti-HIV/Ag p24. J Med Virol 89: 489496.

43. Bremer CM, Saniewski M, Wend UC, Torres $P$, Lelie N, et al. (2009) Transient occult hepatitis $B$ virus infection in a blood donor with high viremia. Transfusion 49: 1621-1629.

44. Weinberger KM, Bauer T, Böhm S, Jilg W (2000) High genetic variability of the group-specific a-determinant of hepatitis $B$ virus surface antigen ( $\mathrm{HBsAg}$ ) and the corresponding fragment of the viral polymerase in chronic virus carriers lacking detectable HBsAg in serum. J Gen Virol 81: 1165-1174.

45. Kremsdorf D, Garreau F, Duclos H, ValerieThiers, H Schellekens, et al. (1993) Complete nucleotide sequence and viral envelope protein expression of a hepatitis $B$ virus DNA derived from a hepatitis $B$ surface antigenseronegative patient. Journal of Hepatology 18: 244-250.

46. Uchida T, Aye TT, Shimojima M, Gotoh K, Shikata T (1994)
Full-length nucleotide sequence of a hepatitis B virus (HBV) mutant isolated from a patient with acute hepatitis who did not exhibit serological markers for HBV infection. Int Hepatol Commun 133: 385-396.

47. Coffin CS, Michalak TI (1999) Persistence of infectious hepadnavirus in the offspring of woodchuck mothers recovered from viral hepatitis. J Clin Invest 104: 203-212.

48. Kwon Cl, Hwang SG, Shin SJ, Chang SW, Kim SY, et al. (2008) Occult hepatitis B virus infection in pregnant woman and its clinical implication. Liver Int 28: 667-674.

49. Bossali F, Paraiso M, Bokossa A, Fourn L (2010) Study of factors influencing hepatitis $B$ immunization coverage in 1 to 8-yearsold children in the Ouidah health district in Benin in 2007. Med Trop (Mars) 70: 149-154.

50. Kiire CF (1996) The epidemiology and prophylaxis of hepatitis $B$ in sub-Saharan Africa: A view from tropical and subtropical Africa. Gut 38: S5-S12. 